\title{
INVESTIGAÇÕES SOBRE METODOLOGIA DE AQUISIÇÃO E INTERPRETAÇÃO DE DADOS SÍSMICOS DE REFLEXÃO RASA PARA IMAGEAMENTO DO TOPO ROCHOSO
}

\author{
Frank Marc Marcelo Le Diagon \\ Orientadora: Dra. Liliana Alcazar Diogo (IAG-USP) \\ 42 p. + anexos - Dissertação (Mestrado) \\ Defesa: $2 / 5 / 2000$
}

\section{RESUMO}

No presente trabalho foram investigadas as técnicas de reflexão sísmica rasa, conhecidas por CMP, janela ótima e afastamento ótimo, para o imageamento da topografia do topo rochoso, cuja profundidade situa-se entre 30 e $60 \mathrm{~m} .0$ estudo foi conduzido com o objetivo de se avaliar a qualidade da imagem obtida em subsuperfície por cada uma das técnicas, em função do custo associado ao levantamento e ao processamento dos dados. Variações para as técnicas existentes foram propostas para investigaçãao, com 0 intuito de diminuir 0 custo de aquisição sem comprometer a resolução do método. A metodologia de trabalho proposta consiste, basicamente, em quatro etapas: 1) execução de testes de campo para auxiliar na determinação dos parâmetros de aquisição dos dados sísmicos de reflexão rasa mais adequados à área investigada; 2) planejamento e execução do levantamento sísmico de modo a compreender todas as técnicas investigadas; 3) seleção, agrupamento e processamento dos registros sísmicos simulando as diferentes técnicas de aquisição; 4) interpretação dos diferentes grupos de registros e comparação entre o custo e qualidade da imagem em subsuperfície obtida em cada técnica. A área selecionada para o desenvolvimento deste trabalho situa-se no campus da Universidade de São Paulo, em um terreno localizado em frente ao Instituto de Física, sendo os levantamentos sísmicos executados ao longo de um perfil leste-oeste paralelo à Rua do Matão. A interpretação dos sismogramas de campo registrados para análise de ruído revelou a necessidade de registrar os sinais refletidos acima do ângulo crítico de incidência, os quais estão conseqüentemente afetados por mudanças de fase. Avaliou-se, com auxílio de dados de refração e da elaboração de sismogramas sintéticos, a viabilidade da interpretação do sinal refletido amostrado para afastamentos maiores do que a distância crítica. Foram executados dois levantamentos de reflexão sísmica rasa, sendo que o segundo corresponde ao prolongamento do primeiro; o que difere nos dois levantamentos é a janela de afastamento fonte-receptor selecionada para a aquisição. Alguns ensaios de refração sísmica rasa foram executados para complementar e auxiliar na interpretação dos dados de reflexão rasa, os quais propiciaram 0 imageamento da base da camada de solo, ao longo da extensão que compreende o primeiro levantamento sísmico de reflexão, e forneceram informações úteis para a definição das velocidades intervalares. Dos resultados obtidos, a seção CMP apresentou melhor razão sinal/ruído e continuidade lateral, com uma pequena deficiência quanto à resolução vertical, devido ao estiramento do sinal após a correção de NMO. A técnica de janela constante não se mostrou a mais adequada para um estudo detalhado da subsuperfície, por fornecer uma seção com baixa razão sinal/ruído e pouca continuidade dos eventos amostrados. A escolha da técnica a ser utilizada depende do objetivo, do nível de detalhe necessário, da complexidade estrutural a ser investigada e do tempo disponível. Quanto mais detalhes forem necessários, mais denso deve ser 0 volume de dados e mais apurado o processamento, conseqüentemente maiores serão os custos e 0 tempo de execução do método.

\section{ABSTRACT}

In this study, three shallow reflection seismic techniques known as CMP, optimum window and optimum offset were investigated in order to image the overburden-bedrock surface, which depth is comprised between 30 and $60 \mathrm{~m}$. The research was carried out to estimate the quality of the subsurface image for each one of the techniques in terms of cost concerning data acquisition and processing. Variations for the existing techniques have been proposed to reduce the cost of the acquiring data without deteriorating the resolution of the method. The methodology of the proposed research consists basically of four steps which are: (1) executing field tests to determine the acquiring parameters that best fit the investigated area; (2) planning and executing the seismic survey including all the investigated techniques; (3) selecting, sorting and processing the seismic records 
simulating the different acquiring techniques; (4) interpreting the different sets of records and comparing the cost and quality of the subsurface image obtained from each technique. The chosen are a for the development of this study is located inside the University of São Paulo, in a field situated in front of the Instituto de Física and the seismic surveys were executed alongside along a east-west profile parallel to Rua do Matão. The walkaway noise tests demonstrate the necessity to acquire the reflected signals beyond the critical angle of incidence, which are consequently affected by dephasing. Using reftacted data and synthetic seismograms, we have estimated the viability to interpret the reflected signal acquired for offsets greater than the critical distance. Two shallow reflection seismic surveys were carried out, being the second an extension of the first one; the difference between the two surveys is the offset window selected for the acquisition. Additional refraction surveys were executed to supplement and assist the interpretation of the shallow reflection data. The results were able to image the base of the soil layer along the profile that includes the first seismic reflection survey, and provide useful information about the interval velocities. Concluding about the application of the investigated techniques, the CMP section has the best signal-to-noise ratio and lateral continuity, but due to stretching after NMO correction has a little deficiency with respect to vertical resolution. The optimum window technique was the less adequate to represent the subsurface because of the observed small signal-to-noise ratio and bad continuity of the reflectors. The choice of the technique depends on the aim, the required resolution, the structural complexities of the investigated area and of the available executing time, A better detailed section requires bulkier data set and more refined data processing, increasing the cost and the executing time of the reflection survey. 